\title{
KEEFEKTIFAN TIGA JENIS INSEKTISIDA NABATI TERHADAP KUTU PUTIH PEPAYA PARACOCCUS MARGINATUS DAN KEAMANANNYA TERHADAP LARVA KUMBANG PREDATOR CURINUS COERULEUS
}

\author{
Ahmad Sifa ${ }^{1}$, Djoko Prijono ${ }^{2}, \&$ Aunu Rauf ${ }^{2}$ \\ ${ }^{1}$ Alumnus Program Sarjana Departemen Proteksi Tanaman, Institut Pertanian Bogor. \\ ${ }^{2}$ Departemen Proteksi Tanaman, Institut Pertanian Bogor \\ Kampus IPB Darmaga, Bogor 16680 \\ E-mail: djokopr@ipb.ac.id
}

\begin{abstract}
Effectiveness of three botanical insecticides against the papaya mealybug Paracoccus marginatus and their safety to the predatory Curinus coeruleus larvae. Preparations of Tephrosia vogelii (Tv) leaf extract $(0.5 \%$ and $1 \%$ w/v), Annona squamosa (As) seed extract $(0.5 \%$ and $1 \%)$, and Cinnamomum multiforum $(\mathrm{Cm})$ leaf essential oil (1\% and $2 \%)$, and their mixtures (Mix-1: Tv 0.25\% + As 0.25\% + Cm 0.5\%; Mix-2: Tv 0.5\% + As 0.5\% + Cm 1\%) were tested for their effectiveness on third-instar nymphs of Paracoccus marginatus by spraying the test materials on undetached papaya leaves and by direct spraying on the test insects using Potter spray tower. Tv extract was also applied on the test insects placed on undetached papaya leaves. The safety test was done by direct spraying of the test materials on the predatory Curinus coeruleus larvae using Potter spray tower. Tv and As extracts at a concentration of $1 \%$ each are potential to be used for the control of $P$. marginatus. Spraying of $T$. vogelii extract on the test $P$. marginatus nymphs placed on papaya leaves was more effective than spraying of the test materials on papaya leaves or direct spraying on the test insects only. The treatment with $\mathrm{Cm}$ essential oil required twice the concentration of $\mathrm{Tv}$ and As extracts to obtain the same level of effectiveness. The treatment with Mix-2 caused lower $P$. marginatus mortality than the sum of mortality caused by its components applied separately. Nonetheless, the three botanical insecticides and their mixtures were safe to $C$. coeruleus larvae. On the other hand, although the synthetic insecticide imidacloprid (neonicotinoid), included in the study for comparison, was effective against $P$. marginatus, it was also toxic to the predatory $C$. coeruleus larvae so its use should be avoided or limited.
\end{abstract}

Key words: botanical insecticides, papaya mealybug, predatory ladybird larvae, effectiveness, safety

\section{ABSTRAK}

Keefektifan tiga jenis insektisida nabati terhadap kutu putih pepaya Paracoccus marginatus dan keamanannya terhadap larva kumbang predator Curinus coeruleus. Sediaan ekstrak daun Tephrosia vogelii (Tv) (0,5\% dan 1\% w/v), ekstrak biji Annona squamosa (As) (0,5\% dan 1\%), dan minyak atsiri daun Cinnamomum multiforum (Cm) (1\% dan 2\%), serta campuran ketiga bahan tersebut (Mix-1: Tv 0,25\% + As 0,25\% + Cm 0,5\%; Mix-2: Tv 0,5\% + As 0,5\% + Cm 1\%) diuji keefektifannya terhadap nimfa instar III Paracoccus marginatus dengan metode penyemprotan pada daun pepaya dan metode semprot langsung pada serangga uji menggunakan menara semprot Potter. Ekstrak Tv juga diaplikasikan pada serangga uji yang diletakkan pada daun pepaya. Uji keamanan insektisida nabati uji dilakukan dengan metode semprot langsung pada larva instar III predator Curinus coeruleus menggunakan menara semprot Potter. Hasil pengujian menunjukkan bahwa ekstrak Tv dan As pada konsentrasi $1 \%$ berpotensi untuk digunakan dalam pengendalian hama P. marginatus. Penyemprotan langsung ekstrak T. vogelii pada nimfa $P$. marginatus yang diletakkan di atas daun pepaya lebih efektif daripada penyemprotan ekstrak pada daun pepaya atau pada serangga uji saja. Perlakuan dengan minyak atsiri $\mathrm{Cm}$ memerlukan konsentrasi dua kali lipat dibandingkan dengan ekstrak Tv dan As untuk memperoleh tingkat keefektifan yang sama. Perlakuan dengan Mix-2 menyebabkan kematian $P$. marginatus yang lebih rendah daripada jumlah kematian yang disebabkan perlakuan dengan bahan tunggal secara terpisah. Namun demikian, ketiga bahan nabati uji dan campurannya aman terhadap larva $C$. coeruleus. Sementara itu, meskipun insektisida sintetik imidakloprid (neonikotinoid), yang disertakan dalam pengujian sebagai insektisida pembanding, efektif terhadap hama $P$. marginatus, insektisida tersebut sangat beracun terhada larva predator $C$. coeruleus sehingga penggunaannya perlu dihindari atau dibatasi.

Kata kunci: insektisida nabati, kutu putih pepaya, predator, keefektifan, keamanan 


\section{PENDAHULUAN}

Kutu putih pepaya, Paracoccus marginatus Williams \& Granara de Willink (Hemiptera: Pseudococcidae), merupakan hama penting yang relatif baru di Indonesia dengan daya merusak yang tinggi. Hama tersebut diketahui pertama kali menyerang tanaman pepaya di Kebun Raya Bogor pada Mei 2008 dan pada Juli 2008 dilaporkan telah banyak merusak pertanaman pepaya milik petani di Bogor (Muniappan et al., 2008). Di Indonesia, pada tahun $2009 P$. marginatus dilaporkan menyerang lebih dari 21 spesies tanaman dari famili Apocynaceae, Araceae, Caricaceae, Convolvulaceae, Cucurbitaceae, Euphorbiaceae, Fabaceae, Malvaceae, Moraceae, Myrtaceae, Rubiaceae, dan Solanaceae (Sartiami et al., 2009).

Di Hawaii, musuh alami yang menyerang $P$. marginatus antara lain predator Cryptolaemus montrouzieri Mulsant, Curinus coeruleus Mulsant, Hyperaspis silvestrii Weise, Symnobius bilucernarius (Mulsant), dan Scymnus sp. (Coleoptera: Coccinellidae), serta Chrysopa sp. (Neuroptera: Chrysopidae); parasitoid Acerophagous papayae Noyes \& Schauff, Anagyrus loecki Noyes \& Menezes, dan Pseudleptomastix mexicana Noyes \& Schauff (Hymenoptera: Encyrtidae); serta cendawan Neozygytes fumosa (Meyerdirk et al., 2004; Heu et al., 2007). Sartiami et al. (2009) melaporkan bahwa predator lokal yang memangsa $P$. marginatus ialah $C$. montrouzieri, Scymnus sp., dan larva Syrphidae (Diptera). Kumbang C. coeruleus yang umum dikenal sebagai predator kutu loncat lamtoro, Heteropsylla cubana Crawford (Hemiptera: Psyllidae) (Wagiman et $a l ., 1990)$, juga pernah ditemukan menyerang hama $P$. marginatus pada tanaman pepaya di Bogor (Pramayudi, 2010). Selanjutnya, parasitoid A. papayae ditemukan memarasit kutu $P$. marginatus yang dikumpulkan dari lapangan di sekitar Kecamatan Darmaga, Bogor (Sutardi, 2011).

Di Indonesia, perkembangan populasi musuh alami lokal belum dapat mengimbangi perkembangan populasi hama $P$. marginatus, terutama pada musim kemarau sehingga dapat terjadi serangan yang berat. Pada keadaan serangan hama $P$. marginatus yang berat, tindakan pengendalian yang sering dilakukan petani ialah pengendalian secara mekanis dengan tangan atau alat bantu mekanis, penyemprotan air dengan tekanan tinggi pada koloni kutu putih, dan penyemprotan air sabun yang diikuti dengan penyemprotan insektisida berbahan aktif imidakloprid (golongan neonikotinoid) (Sartiami et al., 2009).
Ketika musuh alami dan cara-cara nonkimia lain tidak dapat menekan peningkatan populasi hama $P$. marginatus hingga tingkat yang tidak merugikan, insektisida yang efektif terhadap hama sasaran dan aman terhadap musuh alami dapat digunakan sebagai alternatif terakhir. Salah satu kelompok insektisida yang memenuhi persyaratan tersebut dan layak diuji ialah insektisida nabati. Tiga jenis tumbuhan yang telah diketahui bersifat insektisida terhadap hama lain ialah Tephrosia vogelii (kacang babi, Leguminosae), Cinnamomum multiflorum (kerabat kayumanis, Lauraceae), dan Annona squamosa (srikaya, Annonaceae) (Prijono et al., 1997; Abizar \& Prijono, 2010; Hertika, 2011; Febrianni et al., 2013).

Sediaan insektisida dari daun $T$. vogelii efektif terhadap berbagai jenis hama Lepidoptera dan hama kumbang gudang (Grainge \& Ahmed, 1988; Prakash \& Rao, 1997). Ekstrak daun T. vogelii bersifat sebagai racun perut yang kuat dengan efek kontak yang lebih terbatas (Wulan, 2008). Sartiami et al. (2009) melaporkan bahwa penyemprotan dengan air sabun yang diikuti penyemprotan ekstrak daun $T$. vogelii dapat menekan populasi P. marginatus sebesar $35 \%$. Senyawa aktif insektisida yang terkandung dalam daun T. vogelii termasuk dalam golongan rotenoid seperti rotenon, tefrosin, dan deguelin (Delfel et al., 1970; Lambert et al., 1993). Rotenon bekerja dengan menghambat proses respirasi sel di dalam mitokondria (Hollingworth, 2001).

Biji A. squamosa telah lama diketahui bersifat insektisida dan aktif terhadap berbagai jenis serangga pemakan daun dan pengisap cairan tanaman (Grainge \& Ahmed, 1988; Prakash \& Rao, 1997). Prijono et al. (1997) melaporkan bahwa ekstrak biji srikaya memiliki aktivitas insektisida yang kuat terhadap larva Crocidolomia pavonana (F.) (Lepidoptera: Crambidae) dan lebih aktif daripada ekstrak akar tuba, Derris elliptica. Biji srikaya mengandung senyawa aktif insektisida dari golongan asetogenin, terutama skuamosin dan asimisin (Ohsawa et al., 1994; ZafraPolo et al., 1996). Senyawa aktif tersebut memiliki cara kerja yang sama dengan rotenon (Zafra-Polo et al., 1996).

Penelitian tentang aktivitas insektisida $C$. multiforum masih sangat terbatas. Minyak atsiri daun C. multiflorum dilaporkan bersifat insektisida dengan kerja yang cukup cepat terhadap larva $C$. pavonana (Hertika, 2011) dan Plutella xylostella (L.) (Lepidoptera: Yponomeutidae) (Febrianni et al., 2013) tetapi aktivitasnya terhadap hama lain belum pernah diteliti. Minyak atsiri daun $C$. multiflorum mengandung 
metileugenol (area puncak GC 49,4\%) sebagai komponen utama (Hertika, 2011).

Insektisida nabati dapat digunakan secara tunggal dan dalam bentuk campuran. Penggunaan insektisida nabati dalam bentuk campuran dapat menghemat bahan baku bila campuran bersifat sinergis selain dapat memanfaatkan keanekaragaman sumber daya nabati lokal secara optimum (Dadang \& Prijono, 2008). Penggunaan ekstrak daun $T$. vogelii, ekstrak biji $A$. squamosa, dan minyak atsiri daun $C$. multiflorum serta campuran ketiga bahan nabati tersebut diharapkan dapat menekan populasi hama $P$. marginatus sementara di pihak lain dapat melestarikan musuh alami hama tersebut, termasuk kumbang predator $C$. coeruleus.

Penelitian ini bertujuan menentukan keefektifan ekstrak daun $T$. vogelii, ekstrak biji A. squamosa, dan minyak atsiri daun $C$. multiforum, serta campuran ketiga bahan nabati tersebut terhadap hama $P$. marginatus dan keamanannya terhadap larva kumbang predator $C$. coeruleus. Formulasi insektisida sintetik komersial berbahan aktif imidakloprid digunakan sebagai pembanding.

\section{METODE PENELITIAN}

Tempat dan Waktu. Penelitian dilaksanakan di rumah kaca kebun percobaan Cikabayan Institut Pertanian Bogor (IPB) dan Laboratorium Fisiologi dan Toksikologi Serangga, Departemen Proteksi Tanaman, Fakultas Pertanian IPB dari Agustus 2010 sampai Mei 2011.

Perbanyakan Tanaman Pepaya. Tanaman pepaya untuk percobaan ditanam dari bibit pepaya jenis California berumur 2 minggu yang diperoleh dari tempat pembibitan pepaya di desa Rancabungur, Kecamatan Semplak, Kabupaten Bogor. Bibit pepaya ditanam dalam pot plastik kapasitas 2,5 liter. Media tanam yang digunakan adalah tanah dan pupuk kandang dengan perbandingan 1:1.

Perbanyakan Kutu Putih Pepaya $P$. marginatus. Kutu putih pepaya $P$. marginatus diperbanyak dalam kurungan mika-kasa berbingkai kayu berukuran $1 \mathrm{~m} \mathrm{x}$ $0,5 \mathrm{~m} \times 1 \mathrm{~m}$. Tanaman pepaya berumur 2 bulan dimasukkan ke dalam kurungan tersebut kemudian diinfestasi dengan imago $P$. marginatus. Serangga tersebut dibiarkan berkembang biak sampai jumlahnya mencukupi untuk pengujian.

Perbanyakan Kumbang Predator $C$. coeruleus. Kumbang predator $C$. coeruleus dikumpulkan dari tanaman lamtoro di kebun organik Bina Sarana Bakti,
Kecamatan Cisarua, Kabupaten Bogor. Sebanyak 40 ekor imago kumbang predator $C$. coeruleus dengan nisbah kelamin jantan:betina 1:3 (Siswanto \& Soehardjan, 1987) dimasukkan ke dalam kurungan plastik-kasa berbentuk tabung dengan diameter $20 \mathrm{~cm}$ dan tinggi $15 \mathrm{~cm}$ yang bagian bawahnya dialasi tisu. Imago $C$. coeruleus diberi pakan pupa muda lebah madu (Matsuka \& Niijima, 1985). Kertas karton hitam dengan lipatan $1 \mathrm{~cm}$ diletakkan di dalam kurungan tersebut sebagai tempat peletakan telur. Kertas tisu, pakan, dan kertas karton hitam tempat peletakan telur diganti setiap hari. Telur-telur dipisahkan dan dipindahkan ke dalam kurungan plastik yang berbeda.

Bahan Insektisida Nabati Uji. Insektisida nabati uji yang digunakan adalah ekstrak aseton daun $T$. vogelii, ekstrak heksana biji A. squamosa, dan minyak atsiri daun C. multiforum. Potongan daun T. vogelii dan biji A. squamosa digiling dengan blender, kemudian diayak dengan pengayak kawat kasa berjalinan $0,5 \mathrm{~mm}$. Selanjutnya serbuk daun $T$. vogelii diekstrak dengan aseton dan serbuk biji $A$. squamosa diekstrak dengan heksana dengan metode perendaman (maserasi) mengikuti cara ekstraksi yang dikemukakan oleh Abizar $\&$ Prijono (2010). Minyak atsiri C. multiforum disiapkan dengan cara penyulingan dengan alat penyulingan uap air (Hertika, 2011). Formulasi insektisida pembanding Confidor 5 WP (bahan aktif imidakloprid 5\%) dibeli dari salah satu toko pertanian di Bogor.

Pengujian Keefektifan Insektisida Nabati terhadap Nimfa $P$. marginatus. Pengujian keefektifan ekstrak daun $T$. vogelii, ekstrak biji A. squamosa, minyak atsiri daun $C$. multiforum, dan campuran ketiga bahan nabati tersebut terhadap nimfa P. marginatus dilakukan dengan menggunakan tiga metode, yaitu metode semprot daun, semprot serangga, dan semprot serangga pada daun.

Metode semprot daun. Ekstrak daun $T$. vogelii dan ekstrak biji $A$. squamosa diuji pada konsentrasi $0,5 \%$ dan $1 \%(\mathrm{w} / \mathrm{v})$ serta minyak atsiri daun C. multiforum diuji konsentrasi $1 \%$ dan $2 \%$ (w/v). Komposisi dua macam campuran yang diuji masingmasing ekstrak T. vogelii $0,25 \%$ + ekstrak A. squamosa $0,25 \%+$ minyak atsiri C. multiforum $0,5 \%$ (Campuran 1) dan ekstrak T. vogelii $0,5 \%+$ ekstrak A. squamosa $0,5 \%+$ minyak atsiri C. multiforum $1 \%$ (Campuran 2). Setiap bahan insektisida nabati dicampur dengan pelarut metanol, Solvesso R-100, dan pengemulsi Tween-80 (9:1:5) kemudian diencerkan dengen akuades sampai volume tertentu sesuai konsentrasi yang diuji. Konsentrasi akhir metanol, Solvesso R-100, dan Tween- 
80 dalam suspensi uji berturut-turut $0,72 \%, 0,08 \%$, dan $0,4 \%$. Suspensi kontrol berupa campuran pelarut dan pengemulsi tersebut di atas yang diencerkan dengan akuades. Formulasi insektisida pembanding Confidor 5 WP diencerkan dengan akuades pada konsentrasi $0,1 \%$ (w/v). Sediaan insektisida nabati dan insektisida pembanding dimasukkan ke dalam botol semprot yang berbeda, masing-masing dengan kapasitas $50 \mathrm{ml}$.

Satu daun pada tanaman pepaya disemprot pada permukaan atas dan bawah sebanyak 20 kali semprot (volume $\pm 4,4 \mathrm{ml}$ ) dengan sediaan bahan insektisida nabati uji atau insektisida pembanding imidakloprid menggunakan botol semprot kemudian dibiarkan kering. Setelah lapisan bahan uji pada daun mengering, $15 \mathrm{nimfa}$ instar III betina P. marginatus diinfestasikan pada pada setiap daun perlakuan. Selanjutnya, daun percobaan disungkup dengan tabung mika $(\mathrm{p}=35 \mathrm{~cm}, \mathrm{~d}=16 \mathrm{~cm})$ yang kedua ujungnya ditutup kain kasa. Jumlah kutu yang mati dicatat pada 24,48 , dan 72 jam setelah perlakuan (JSP).

Percobaan disusun dalam rancangan acak lengkap dengan 10 perlakuan dan 5 ulangan. Data kematian serangga uji pada setiap waktu pengamatan diolah dengan sidik ragam yang dilanjutkan dengan uji selang berganda Duncan pada taraf nyata $5 \%$ untuk pembandingan nilai tengah antarperlakuan. Analisis statistika tersebut dilakukan menggunakan paket program SAS 9.1 (SAS Institute 2002).

Metode semprot serangga. Penyiapan sediaan insektisida nabati uji dan insektisida pembanding sama seperti pada metode semprot daun. Nimfa instar III betina $P$. marginatus sebanyak 15 individu ditempatkan pada bagian dasar cawan petri berdiameter $9 \mathrm{~cm}$ kemudian disemprot dengan sediaan insektisida nabati uji atau insektisida pembanding imidakloprid dengan volume semprot $5 \mathrm{ml} /$ perlakuan menggunakan menara semprot (spray tower) Potter (Yu, 2008). Kutu yang telah disemprot diinfestasikan pada satu daun pepaya kemudian disungkup dengan tabung mika-kasa seperti di atas. Jumlah kutu yang mati dihitung pada 24 , 48, dan 72 JSP. Rancangan percobaan dan analisis data sama seperti pada percobaan sebelumnya.

Metode semprot serangga pada daun. Pada pengujian ini digunakan ekstrak daun T. vogelii $0,5 \%$ dan $1 \%$. Penyiapan sediaan ekstrak tersebut sama seperti pada pengujian sebelumnya. Nimfa instar III betina $P$. marginatus sebanyak 15 individu diletakkan pada permukaan atas daun pepaya kemudian disemprot dengan sediaan ekstrak $T$. vogelii sebanyak 10 kali semprot (volume $\pm 2,2 \mathrm{ml}$ ) menggunakan botol semprot
$50 \mathrm{ml}$. Daun pepaya perlakuan beserta serangga uji disungkup dengan tabung mika-kasa seperti di atas. Jumlah kutu yang mati dihitung pada 24, 48, dan 72 JSP. Rancangan percobaan dan analisis data sama seperti pada percobaan sebelumnya tetapi pada pengujian ini hanya terdapat tiga perlakuan, yaitu ekstrak $T$. vogelii $0,5 \%$ dan $1 \%$ serta kontrol.

\section{Pengujian Keamanan Insektisida Nabati terhadap}

Larva $C$. coeruleus. Macam perlakuan serta penyiapan sediaan insektisida nabati uji dan insektisida pembanding sama seperti pada pengujian terhadap nimfa $P$. marginatus. Larva instar III C. coeruleus sebanyak 10 individu ditempatkan pada bagian dasar cawan petri berdiameter $9 \mathrm{~cm}$ kemudian disemprot dengan sediaan insektisida nabati uji atau insektisida pembanding imidakloprid dengan volume semprot $5 \mathrm{ml} /$ perlakuan menggunakan menara semprot Potter. Larva $C$. coeruleus yang telah disemprot dipindahkan ke cawan petri yang dialasi tisu dan diberi pakan pupa muda lebah madu. Jumlah serangga yang mati dihitung pada 24,48 , dan 72 JSP. Rancangan percobaan dan analisis data sama seperti pada percobaan sebelumnya.

\section{HASIL DAN PEMBAHASAN}

\section{Keefektifan Insektisida Nabati Uji terhadap Nimfa $P$. marginatus.}

Metode semprot daun. Perlakuan dengan tiga jenis insektisida nabati uji dan campurannya, masingmasing pada dua taraf konsentrasi, mengakibatkan mortalitas nimfa instar III betina $P$. marginatus yang beragam. Mortalitas nimfa $P$. marginatus pada semua perlakuan insektisida nabati pada 24 JSP tidak melebihi $25 \%$ dan mortalitas serangga uji pada perlakuan insektisida pembanding imidakloprid juga masih rendah, yaitu hanya $33,3 \%$, sedangkan pada kontrol tidak ada kematian serangga uji (Tabel 1). Insektisida nabati pada konsentrasi yang lebih tinggi mengakibatkan mortalitas serangga uji lebih tinggi.

Mortalitas serangga uji pada perlakuan dengan ekstrak biji A. squamosa $1 \%$ dan minyak atsiri daun $C$. multiforum $2 \%$ tidak berbeda nyata dengan perlakuan formulasi imidakloprid $0,1 \%$ pada 24 JSP. Hal ini menunjukkan bahwa ekstrak biji A. squamosa dan minyak atsiri daun $C$. multiforum memiliki efek kontak awal yang cukup cepat. Ekstrak biji A. squamosa mengandung senyawa aktif golongan asetogenin, terutama skuamosin dan asimisin, yang bersifat sebagai racun perut dan racun kontak yang kuat terhadap beberapa jenis serangga (Ohsawa et al., 1994). Minyak atsiri daun $C$. multiforum mengandung metileugenol 
sebagai komponen utama dan memiliki aktivitas insektisida yang kuat dengan efek kerja yang cepat terhadap ulat krop kubis C. pavonana (Hertika, 2011). Sementara itu, imidakloprid merupakan insektisida kimia sintetik golongan neonikotinoid yang selain bersifat sistemik juga memiliki efek kontak yang baik dengan cara kerja sebagai racun saraf yang (Cox 2001; Brown et al. 2006). Imidakloprid efektif terhadap berbagai jenis serangga menusuk-mengisap dan beberapa jenis serangga pemakan daun (NPIC, 2010).

Pada semua perlakuan insektisida nabati, mortalitas serangga uji meningkat cukup besar pada 48 dan 72 JSP. Kontak antara serangga uji dengan lapisan residu insektisida pada permukaan daun secara terusmenerus mengakibatkan akumulasi senyawa aktif yang terserap ke dalam tubuh melalui kemoreseptor pada tarsus. Perlakuan dengan imidakloprid $0,1 \%$ yang memiliki efek kontak yang kuat meningkatkan mortalitas serangga uji dengan tajam pada 48 JSP dan mortalitas serangga uji mencapai $100 \%$ pada 72 JSP (Tabel 1). Seperti pada pengamatan 24 JSP, perlakuan dengan ketiga jenis insektisida nabati dan campurannya pada konsentrasi yang lebih tinggi mengakibatkan mortalitas serangga uji yang lebih tinggi pula pada 48 dan 72 JSP, sementara pada kontrol tidak ada kematian serangga uji. Mortalitas serangga uji pada perlakuan imidakloprid $0,1 \%$ lebih tinggi daripada semua perlakuan lain, baik pada 48 JSP maupun 72 JSP. Mortalitas serangga uji akibat perlakuan insektisida nabati pada konsentrasi yang lebih tinggi berkisar antara $52 \%$ dan $65 \%$ pada 48 JSP yang tidak berbeda nyata di antara perlakuan tersebut. Pada 72 JSP, mortalitas serangga uji pada perlakuan ekstrak daun $T$. vogelii $1 \%$ lebih tinggi dibandingkan dengan perlakuan insektisida nabati lainnya tetapi tidak berbeda nyata dengan mortalitas pada perlakuan minyak atsiri daun C. multiforum $2 \%$ dan Campuran 2 (Tabel 1). Daun T. vogelii mengandung senyawa rotenoid yang bersifat insektisida, terutama rotenon, tefrosin, dan deguelin (Delfel et al., 1970; Lambert et al., 1993). Rotenon memiliki aktivitas insektisida yang kuat terhadap berbagai jenis serangga, terutama sebagai racun perut (Prakash \& Rao, 1997; Djojosumarto, 2008). Rotenon bekerja sebagai racun respirasi sel di dalam mitokondria yang mengakibatkan serangga kekurangan energi, kematian sel dan jaringan, dan akhirnya mengakibatkan kematian serangga (Hollingworth, 2001).

Pada 24 dan 48 JSP mortalitas serangga uji pada perlakuan Campuran 2 lebih rendah daripada mortalitas akibat perlakuan ekstrak biji $A$. squamosa $1 \%$ dan minyak atsiri daun C. multiforum $2 \%$ serta tidak berbeda nyata dengan mortalitas pada perlakuan ekstrak daun T. vogelii $1 \%$, sementara pada 72 JSP mortalitas pada perlakuan Campuran 2 lebih rendah dibandingkan dengan ekstrak daun $T$. vogelii $1 \%$ dan minyak atsiri daun $C$. multiforum $2 \%$ serta tidak berbeda nyata dengan mortalitas pada perlakuan ekstrak biji A. squamosa $1 \%$. Baik pada konsentrasi rendah maupun yang lebih tinggi,

Tabel 1. Mortalitas kutu putih pepaya P. marginatus akibat perlakuan dengan insektisida nabati uji dan imidakloprid dengan metode semprot daun

\begin{tabular}{lccc}
\hline & \multicolumn{3}{c}{ Rata-rata mortalitas (\%) pada n JSP $^{\mathrm{a}}$} \\
\cline { 2 - 4 } Perlakuan & 24 & 48 & 72 \\
\hline T. vogelii 0,5\% & $10,7 \mathrm{bc}$ & $40,0 \mathrm{~cd}$ & $56,0 \mathrm{~d}$ \\
T. vogelii 1\% & $16,0 \mathrm{bc}$ & $52,0 \mathrm{bc}$ & $84,0 \mathrm{~b}$ \\
A. squamosa 0,5\% & $12,0 \mathrm{bc}$ & $25,3 \mathrm{e}$ & $32,0 \mathrm{e}$ \\
A. squamosa 1\% & $22,7 \mathrm{ab}$ & $58,7 \mathrm{~b}$ & $73,3 \mathrm{c}$ \\
C. multiforum 1\% & $6,7 \mathrm{c}$ & $22,7 \mathrm{e}$ & $33,3 \mathrm{e}$ \\
C. multiforum 2\% & $22,7 \mathrm{ab}$ & $65,3 \mathrm{~b}$ & $81,3 \mathrm{bc}$ \\
Campuran 1 & $6,7 \mathrm{c}$ & $29,3 \mathrm{de}$ & $62,7 \mathrm{~d}$ \\
Campuran 2 & $16,0 \mathrm{bc}$ & $54,7 \mathrm{~b}$ & $76,0 \mathrm{bc}$ \\
Imidakloprid 0,1\% & $33,3 \mathrm{a}$ & $93,3 \mathrm{a}$ & $100,0 \mathrm{a}$ \\
Kontrol & $0,0 \mathrm{~d}$ & $0,0 \mathrm{f}$ & $0,0 \mathrm{f}$ \\
\hline
\end{tabular}

a JSP: jam setelah perlakuan. ${ }^{\mathrm{b}}$ Campuran 1: ekstrak T. vogelii $0,25 \%+$ A. squamosa $0,25 \%+C$. multiforum 0,5\%.Campuran 2: ekstrak T. vogelii $0,5 \%+$ A. squamosa $0,5 \%+C$. multiforum $1 \%$. Angka yang diikuti huruf yang sama dalam kolom yang sama menunjukkan tidak berbeda nyata menurut uji Duncan $\alpha=0,05$. 
konsentrasi komponen dalam campuran hanya setengah konsentasi komponen masing-masing pada pengujian ekstrak tunggal (Tabel 1). Untuk meningkatkan keefektifan campuran, konsentrasi komponen campuran dapat ditingkatkan hingga menyamai konsentrasi komponen masing-masing pada pengujian secara terpisah.

Metode semprot serangga. Mortalitas nimfa instar III betina $P$. marginatus akibat perlakuan dengan tiga jenis insektisida nabati dan campurannya, baik pada konsentrasi tinggi maupun yang lebih rendah, meningkat selama periode pengamatan (24 sampai 72 JSP). Mortalitas $P$. marginatus akibat perlakuan dengan imidakloprid meningkat dari $87 \%$ pada 24 JSP sampai $100 \%$ pada 72 JSP sementara pada kontrol tidak ada serangga uji yang mati (Tabel 2). Pada setiap waktu pengamatan, mortalitas $P$. marginatus akibat perlakuan dengan imidakloprid nyata lebih tinggi daripada mortalitas serangga uji pada semua perlakuan insektisida nabati baik tunggal maupun campuran. Hal tersebut menunjukkan bahwa imidakloprid memiliki efek kontak langsung yang jauh lebih kuat daripada ketiga jenis insektisida nabati uji.

Mortalitas P. marginatus akibat perlakuan dengan insektisida nabati uji pada konsentrasi yang lebih tinggi berkisar dari $12 \%$ sampai $20,2 \%$ pada 24 JSP, $26,7 \%$ $33,3 \%$ pada 48 JSP, dan $37,3 \%-48 \%$ pada 72 JSP dengan mortalitas tertinggi terdapat pada perlakuan dengan ekstrak $T$. vogelii tetapi di antara perlakuan insektisida nabati tidak terdapat perbedaan mortalitas yang nyata. Pada konsentrasi yang lebih rendah juga tidak terdapat perbedaan mortalitas yang nyata di antara perlakuan insektisida nabati pada ketiga waktu pengamatan (Tabel 2). Pada pengujian ini penyemprotan insektisida nabati pada serangga uji hanya dilakukan satu kali tetapi mortalitas serangga uji masih meningkat pada 48 dan 72 JSP. Hal ini menunjukkan bahwa penetrasi senyawa aktif ketiga jenis insektisida nabati uji melalui kutikula nimfa $P$. marginatus berlangsung lambat.

Imidakloprid sangat efektif terhadap $P$. marginatus baik dengan metode semprot daun (Tabel 1) maupun dengan metode semprot serangga (Tabel 2), yang menunjukkan bahwa insektisida tersebut memiliki efek kontak yang kuat terhadap $P$. marginatus. Sementara itu, mortalitas $P$. marginatus akibat perlakuan dengan insektisida nabati uji pada metode semprot serangga jauh lebih rendah daripada mortalitas pada metode semprot daun, yang menunjukkan bahwa insektisida nabati uji memiliki efek kontak langsung yang relatif terbatas. Mortalitas $P$. marginatus akibat perlakuan campuran insektisida nabati pada konsentrasi yang lebih tinggi secara umum lebih rendah daripada mortalitas serangga uji pada perlakuan masing-masing ekstrak secara terpisah meskipun secara statistika tidak berbeda nyata. Seperti pada pengujian dengan metode semprot daun, untuk meningkatkan keefektifan campuran secara kontak langsung, konsentrasi

Tabel 2. Mortalitas kutu putih pepaya $P$. marginatus akibat perlakuan insektisida nabati uji dan imidakloprid dengan metode semprot serangga

\begin{tabular}{lccc}
\hline & \multicolumn{3}{c}{ Rata-rata mortalitas (\%) pada n JSP $^{\mathrm{a}}$} \\
\cline { 2 - 4 } Perlakuan & 24 & 48 & 72 \\
\hline T. vogelii 0,5\% & $6,7 \mathrm{de}$ & $14,7 \mathrm{c}$ & $25,3 \mathrm{c}$ \\
T. vogelii 1\% & $20,2 \mathrm{~b}$ & $33,3 \mathrm{~b}$ & $48,0 \mathrm{~b}$ \\
A. squamosa 0,5\% & $9,3 \mathrm{bcde}$ & $17,3 \mathrm{c}$ & $24,0 \mathrm{c}$ \\
A. squamosa 1\% & $16,0 \mathrm{~b}$ & $28,0 \mathrm{~b}$ & $41,3 \mathrm{~b}$ \\
C. multiforum 1\% & $5,3 \mathrm{e}$ & $14,7 \mathrm{c}$ & $21,3 \mathrm{c}$ \\
C. multiforum 2\% & $13,3 \mathrm{bc}$ & $26,7 \mathrm{~b}$ & $38,7 \mathrm{~b}$ \\
Campuran 1 & $6,7 \mathrm{cde}$ & $16,0 \mathrm{c}$ & $20,0 \mathrm{c}$ \\
Campuran 2 & $12,0 \mathrm{bcd}$ & $26,7 \mathrm{~b}$ & $37,3 \mathrm{~b}$ \\
Imidakloprid 0,1\% & $86,7 \mathrm{a}$ & $98,7 \mathrm{a}$ & $100,0 \mathrm{a}$ \\
Kontrol & $0,0 \mathrm{f}$ & $0,0 \mathrm{~d}$ & $0,0 \mathrm{~d}$ \\
\hline
\end{tabular}

a JSP: jam setelah perlakuan. ${ }^{\mathrm{b}}$ Campuran 1: ekstrak T. vogelii $0,25 \%+$ A. squamosa $0,25 \%+C$. multiforum 0,5\%.Campuran 2: ekstrak T. vogelii $0,5 \%+$ A. squamosa $0,5 \%+C$. multiforum $1 \%$. Angka yang diikuti huruf yang sama dalam kolom yang sama menunjukkan tidak berbeda nyata menurut uji Duncan $\alpha=0,05$ 
komponen campuran dapat ditingkatkan hingga menyamai konsentrasi komponen masing-masing pada pengujian secara terpisah.

Metode semprot serangga pada daun. Mortalitas nimfa instar III $P$. marginatus pada metode semprot serangga pada daun (Tabel 3) lebih tinggi daripada mortalitas pada metode semprot daun (Tabel 1) dan metode semprot serangga (Tabel 2). Hal ini karena senyawa aktif $T$. vogelii terserap ke dalam tubuh kutu P. marginatus melalui dua cara, yaitu melalui bagian tarsus tungkai kutu yang kontak dengan lapisan residu pada permukaan daun dan melalui kutikula tubuh akibat terkena semprotan langsung. Pada 24 JSP, mortalitas $P$. marginatus akibat perlakuan dengan ekstrak $T$. vogelii $0,5 \%$ dan $1 \%$ masing-masing sudah melebihi $65 \%$ kemudian meningkat menjadi $73 \%$ dan $88 \%$ pada 48
JSP serta $84 \%$ dan $96 \%$ pada 72 JSP (Tabel 3). Hal ini menunjukkan bahwa ekstrak $T$. vogelii cukup potensial untuk digunakan dalam pengendalian hama kutu $P$. marginatus dengan cara penyemprotan hama tersebut pada tanaman pepaya.

Keamanan Insektisida Nabati Uji terhadap Larva C. coeruleus. Perlakuan dengan ekstrak T. vogelii $1 \%$, A. squamosa $1 \%$, minyak atsiri C. multiflorum $2 \%$ dan Campuran 2 menyebabkan mortalitas larva instar III $C$. coeruleus berturut-turut $6 \%, 2 \%, 12 \%$, dan $4 \%$. Mortalitas larva $C$. coeruleus tidak meningkat lagi pada 48 dan 72 JSP (Tabel 4). Pada konsentrasi yang lebih rendah, mortalitas serangga uji juga lebih rendah, sementara serangga kontrol tidak ada yang mati. Perlakuan dengan formulasi imidakloprid $1 \%$ mengakibatkan mortalitas larva $C$. coeruleus yang

Tabel 3. Mortalitas kutu putih pepaya $P$. marginatus akibat perlakuan dengan ekstrak $T$. vogelii dengan metode semprot serangga pada daun

\begin{tabular}{lrcr}
\hline Konsentrasi & \multicolumn{3}{c}{ Rata-rata mortalitas (\%) pada n JSP $^{\mathrm{a}}$} \\
\cline { 2 - 4 }$(\%, \mathrm{w} / \mathrm{v})$ & 24 & 48 & 72 \\
\hline 0,5 & $65,3 \mathrm{~b}$ & $73,3 \mathrm{~b}$ & $84,0 \mathrm{~b}$ \\
1 & $78,7 \mathrm{a}$ & $88,0 \mathrm{a}$ & $96,0 \mathrm{a}$ \\
Kontrol & $0,0 \mathrm{c}$ & $0,0 \mathrm{c}$ & $0,0 \mathrm{c}$ \\
\hline
\end{tabular}

a JSP: jam setelah perlakuan. Angka yang diikuti huruf yang sama dalam kolom yang sama menunjukkan tidak berbeda nyata menurut uji Duncan $\alpha=0,05$.

Tabel 4. Mortalitas larva kumbang predator $C$. coeruleus akibat perlakuan insektisida nabati uji dan imidakloprid dengan metode semprot serangga

\begin{tabular}{lccc}
\hline & \multicolumn{3}{c}{ Rata-rata mortalitas (\%) pada n JSP $^{\mathrm{a}}$} \\
\cline { 2 - 4 } Perlakuan & 24 & 48 & 72 \\
\hline T. vogelii $0,5 \%$ & $2 \mathrm{c}$ & $2 \mathrm{c}$ & $2 \mathrm{c}$ \\
T. vogelii $1 \%$ & $6 \mathrm{bc}$ & $6 \mathrm{bc}$ & $6 \mathrm{bc}$ \\
A. squamosa $0,5 \%$ & $0 \mathrm{c}$ & $0 \mathrm{c}$ & $0 \mathrm{c}$ \\
A. squamosa $1 \%$ & $2 \mathrm{c}$ & $2 \mathrm{c}$ & $2 \mathrm{c}$ \\
C. multiforum $1 \%$ & $6 \mathrm{bc}$ & $6 \mathrm{bc}$ & $6 \mathrm{bc}$ \\
C. multiforum $2 \%$ & $12 \mathrm{~b}$ & $12 \mathrm{~b}$ & $12 \mathrm{~b}$ \\
Campuran $1^{\mathrm{b}}$ & $0 \mathrm{c}$ & $0 \mathrm{c}$ & $0 \mathrm{c}$ \\
Campuran 2 & $4 \mathrm{bc}$ & $4 \mathrm{bc}$ & $4 \mathrm{bc}$ \\
Imidakloprid $0,1 \%$ & $92 \mathrm{a}$ & $100 \mathrm{a}$ & $100 \mathrm{a}$ \\
Kontrol & $0 \mathrm{c}$ & $0 \mathrm{c}$ & $0 \mathrm{c}$ \\
\hline
\end{tabular}

a JSP: jam setelah perlakuan. ${ }^{\mathrm{b}}$ Campuran 1: ekstrak T. vogelii $0,25 \%+$ A. squamosa $0,25 \%+$ C. multiforum 0,5\%.Campuran 2: ekstrak T. vogelii $0,5 \%+$ A. squamosa $0,5 \%+C$. multiforum $1 \%$. Angka yang diikuti huruf yang sama dalam kolom yang sama menunjukkan tidak berbeda nyata menurut uji Duncan $\alpha=0,05$ 
tinggi, yaitu meningkat dari $92 \%$ pada 24 JSP menjadi $100 \%$ pada 48 JSP.

Hasil penelitian ini menunjukkan bahwa perlakuan dengan ekstrak daun $T$. vogelii, ekstrak biji $A$. squamosa, dan minyak atsiri daun $C$. multiflorum serta campuran ketiga bahan nabati tersebut mengakibatkan mortalitas yang lebih tinggi pada nimfa $P$. marginatus dibandingkan dengan pada larva predator $C$. coeruleus. Penyemprotan ekstrak $T$. vogelii terhadap kutu $P$. marginatus yang terdapat pada tanaman lebih efektif daripada penyemprotan bahan uji pada daun atau penyemprotan langsung pada serangga saja. Keefektifan ekstrak A. squamosa dan minyak atsiri $C$. multiflorum diharapkan juga akan meningkat seperti ekstrak $T$. vogelii bila penyemprotan juga dilakukan terhadap kutu $P$. marginatus yang sudah terdapat pada bagian tanaman. Sementara itu, imidakloprid selain efektif terhadap hama $P$. marginatus juga beracun terhadap predator $C$. coeruleus sehingga penggunaannya perlu dihindari atau dibatasi.

\section{SIMPULAN}

Ekstrak daun $T$. vogelii dan ekstrak biji $A$. squamosa cukup potensial untuk digunakan dalam pengendalian hama kutu putih pepaya $P$. marginatus, sementara minyak atsiri daun $C$. multiflorum memiliki keefektifan yang lebih rendah dibandingkan dengan kedua ekstrak tersebut. Perlakuan ekstrak T. vogelii dengan metode penyemprotan serangga pada daun tanaman inang lebih efektif dibandingkan dengan metode semprot daun atau semprot serangga saja. Ketiga jenis insektisida nabati uji aman terhadap larva predator $C$. coeruleus. Sementara itu, insektisida pembanding imidakloprid selain efektif terhadap kutu $P$. marginatus juga beracun terhadap larva predator $C$. coeruleus sehingga penggunaannya perlu dihindari atau dibatasi.

Perlu dilakukan pengujian insektisida nabati dari bahan tumbuhan lain sebagai alternatif untuk mengendalikan hama $P$. marginatus. Pengujian terhadap predator jenis lain, parasitoid, atau musuh alami lainnya juga perlu dilakukan agar didapatkan beberapa insektisida nabati yang efektif terhadap hama sasaran dan aman terhadap musuh alami hama.

\section{SANWACANA}

Penulis mengucapkan terima kasih kepada Pengelola Program Riset Insentif, Kementerian Negara Riset dan Teknologi atas dukungan dana penelitian dengan Kontrak No. 021/RT/D.PSIPTN/Insentif/PPK/
I/2010. Penulis juga mengucapkan terima kasih kepada Sdr. Saodik atas bantuan teknisnya.

\section{DAFTAR PUSTAKA}

Abizar M \& Prijono D. 2010. Aktivitas insektisida ekstrak daun dan biji Tephrosia vogelii J.D. Hooker (Leguminosae) dan ekstrak buah Piper cubeba L. (Piperaceae) terhadap larva Crocidolomia pavonana (F.) (Lepidoptera: Crambidae). JHPT Tropika. 10: 1-12.

Brown LA, Ihara M, Buckingham SD, Matsuda K, \& Sattelle DB. 2006. Neonicotinoid insecticides display partial and superagonist actions on native insect nicotinic acetylcholine receptors. $J$. Neurochem. 99: 608-615.

Cox C. 2001. Imidacloprid. J. Pestic.Reform.21:15-21.

Dadang \& Prijono D. 2008. Insektisida Nabati: Prinsip, Pemanfaatan, dan Pengembangan. DepartemenProteksiTanaman, Institut Pertanian Bogor, Bogor.

Delfel NE, Tallent WH, Carlson DG, \& Wolf IA. 1970. Distribution of rotenone and deguelin in Tephrosia vogelii and separation of rotenoid-rich fractions. J. Agric. Food Chem. 18: 385-390.

Djojosumarto P. 2008. Pestisida dan Aplikasinya. Agromedia, Jakarta.

Febrianni A, Prijono D, \& Rauf A. 2013. Aktivitas insektisida ekstrak biji Annona squamosa, minyak atsiri daun Cinnamomum multiflorum, ekstrak daun Tephrosia vogelii, dan campuran ketiganya terhadap larva Plutella xylostella. Hlm 453-462 dalam: Prosiding Seminar Nasional dan Lokakarya Forum Komunikasi Perguruan Tinggi Pertanian Indonesia. Bogor, 2-4 September 2013. Fakultas Pertanian, Institut Pertanian Bogor, Bogor.

Grainge M \& Ahmed S. 1988. Handbook of Plants with Pest Control Properties. John Wiley \& Sons, New York.

Hertika C. 2011. Aktivitas insektisida minyak atsiri daun Cinnamomum spp. (Lauraceae) terhadap ulat kubis Crocidolomia pavonana dan pengaruh fitotiksisitas pada bibit brokoli [Skripsi]. Departemen Kimia, Fakultas MIPA, Institut Pertanian Bogor, Bogor. 
Heu RA, Fukada MT, \& Conant P. 2007. Papaya mealybug Paracoccus marginatus Willian and Granara de Willink (Hemiptera: Pseudococcidae). State of Hawaii Departement of Agriculture, Honolulu. http://hawaii.gov/hdoa/pi/ppc/npa-1/ npa04-03-PMB.pdf. [diakses 16 Januari 2011].

Hollingworth RM. 2001. Inhibitors and uncouplers of mitochondrial oxidative phosphorylation. Pp. 11691227 in: Krieger, R, J Doull, D Ecobichon, D Gammon, \& E Hodgson et al., eds. Handbook of Pesticide Toxicology. Vol 2. Academic Press, San Diego.

Lambert N, Trouslot MF, Campa CN, \& Chrestin H. 1993. Production of rotenoids by heterotrophic and photomixotrophic cell cultures of Tephrosia vogelii. Phytochemistry 34: 1515-1520.

Matsuka M \& Niijima K. 1985. Harmonia axiridis. Pp. 265-268 in: Singh P \& Moore RF (eds.). Handbook of Insect Rearing. Vol.1. Amsterdam, Elsevier.

Meyerdirk DE, Muniappan R, Warkentin R, Bamba J, \& Reddy GVP. 2004. Biological control of the papaya mealybug, Paracoccus marginatus (Hemiptera: Pseudococcidae) in Guam. Plant Prot. Quart. 19:110-114.

Muniappan R, Shepard BM, Watson GW, Carner GR, Sartiami D, Rauf A, \& Hammig MD. 2008. First report of the papaya mealybug, Paracoccus marginatus (Hemiptera: Pseudococcidae), in Indonesia and India. J. Agric. Urban Entomol. 25: 37-40.

[NPIC] National Pesticide Information Center. 2010. Imidacloprid: technical fact sheet. http:// npic.orst.edu/factsheets/imidacloprid.pdf. [diakses 26 Juni 2011].

Ohsawa K, Kato S, \& Manuwoto S. 1994. Bio-active substances from tropical plants. Pp.65-72 in: Sanches FF \& Ohsawa K (eds.). Natural Bioactive Substances in Tropical Plants. Tokyo University of Agriculture, Tokyo.

Prakash A \& Rao J. 1997. Botanical Pesticides in Agriculture. Lewis Publishers, Boca Raton.

Pramayudi N. 2010. Neraca hayati dan pemangsaan Curinus coeruleus Mulsant (Coleoptera: Coccinellidae) pada kutu putih pepaya, Paracoccus marginatus Williams \& Granara de Willink (Hemiptera: Pseudococcidae) [Tesis].
Sekolah Pascasarjana, Institut Pertanian Bogor, Bogor.

Prijono D, Gani MS, \& Syahputra E. 1997. Insecticidal activity of annonaceous seed extracts against Crocidolomia binotalis Zeller (Lepidoptera: Pyralidae). Bul. HPT 9: 1-6.

Sartiami D, Dadang, Anwar R, \& Harahap IS. 2009. Persebaran hama baru Paracoccus marginatus di Provinsi Jawa Barat, Banten, dan DKI Jakarta. Hlm 453-462 dalam: Prosiding Seminar Nasional Perlindungan Tanaman. Bogor, 5-6 Agustus 2009. Pusat Kajian Pengendalian Hama Terpadu IPB, Bogor.

SAS Institute. 2002. SAS 9.1 TS Level 1M3. SAS Institute, Cary.

Siswanto \& M Soehardjan. 1987. Pengaruh nisbah kelamin terhadap produksi telur Curinus coeruleus Mulsant (Coleoptera: Coccinellidae). Makalah disampaikan pada Kongres Entomologi III Perhimpunan Entomologi Indonesia. Jakarta, 30 September - 2 Oktober 1987. 6 hlm.

Sutardi S. 2011. Ciri morfologi dan siklus hidup parasitoid Acerophagus papayae Noyes \& Schauff (Hymenoptera: Encyrtidae) pada Paracoccus marginatus Williams \& Granara de Willink (Hemiptera: Pseudococcidae) [Skripsi]. Departemen Proteksi Tanaman, Fakultas Pertanian, Institut Pertanian Bogor, Bogor.

Wagiman FX, Mangoendihardjo, S \& Mahrub E. 1990. Performance of Curinus coeruleus Mulsant as a predator against Leucaena psyllid. Pp.163-165 in: Napompeth B \& MacDicken KG (eds.). Leucaena Psyllid: Problems and Management. Proceedings of an International Workshop. Bogor, 16-21 Jan 1989. Winrock International, Arlington.

Wulan RDR. 2008. Aktivitas insektisida ekstrak daun Tephrosia vogelli Hook. f. (Leguminosae) terhadap larva Crocidolomia pavonana (F.) (Lepidoptera: Pyralidae) [skripsi]. Departemen Proteksi Tanaman, Fakultas Pertanian, Institut Pertanian Bogor, Bogor.

Yu SJ. 2008. The Toxicology and Biochemistry of Insecticides. CRC Press, Boca Raton.

Zafra-Polo MC, Gonzales MC, Estornell E, Sahpaz S, \& Cortez D. 1996. Acetogenins from Annonaceae, inhibitors of mitochondrial complex I. Phytochemistry 42: 253-271. 